\title{
Obituary
}

Editor: Henry R. Rollin

Harry Pozner, MC, formerly Consultant Psychiatrist, 3 Crabtree Gardens, Headley, Bordon, Hampshire

Brigadier Harry Pozner, a Foundation Fellow of the College, died on 21 February 1988. He was born in Rugby on 10 October 1914. Harry was educated first in France and later graduated in medicine at University Hospital, London. He was commissioned in the Royal Army Medical Corps on 4 October 1939. His war-time service included North West Europe in 1940; India, Assam and Burma from 1943 to 1945, where he was awarded the Military Cross.

His post war appointments included Command Psychiatrist, Eastern and Southern Commands; Adviser in Psychiatry, British Army of the Rhine and Professor of Army Psychiatry. He commanded the Cambridge Military Hospital and the Royal Victoria Hospital, Netley, where he was promoted to the rank of Brigadier. His numerous publications are characterised by an elegant style and an incisive wit.

He retired from the Army in 1974, but his devotion to the interests of Servicemen remained. He was very proud of his association with the Dunkirk Veterans and was the President of the Aldershot branch for many years. It was a touching sight to see its members parade at Harry's funeral and to hear them sound the Last Post. Following retirement, he worked as a civilian medical practitioner at Bordon, but his affection for his first Command, the Cambridge Military Hospital, endured and he was a frequent visitor to the Post Graduate Medical Centre there.

Harry was a warm-hearted, loveable person who attracted a large circle of friends. He was a very enter- taining raconteur. He was a caring and compassionate man, always ready with a helping hand. The love of his wife, Andree, his son, Michael, and his two grandchildren were always with him.

JFDM

Harry Pozner's war service was colourful, distinguished, and gallant. On his return from Dunkirk in 1940, he joined the new Commando Force on its formation, and served with it until his posting to India in 1943. On his arrival there, he promptly volunteered for parachute service, and joined what was then the only Indian Parachute Field Ambulance. The Indian Parachute Brigade's first action was at Sangshak, on the Assam-Burma border, and its task was to deny to a substantially superior Japanese force the road to the great base at Imphal. In the course of the action, the dressing station was over-run. Harry later led a party back into it, to recover desperately needed drugs, dressings, and infusion fluids. It was in this vicious little seven-day battle, in which he was slightly wounded, that Harry earned his Military Cross.

When the Brigade returned to India, Harry was posted to the Indian Army Airborne Forces Research Establishment, where he contributed to research into air-drops of men and medical supplies.

On his eventual return to the UK, Harry embarked on his psychiatric career. There is no doubt but that his personality, and his proven record of military virtues, enhanced and sustained the reputation of Army psychiatry in the post-war years.

PGMcG

\section{WiLliam Sargant}

A Thanksgiving Service for Dr William Sargant will be held at St Marylebone Parish Church, Marylebone
Road, London NW1 at 12 noon on Thursday, 10 November 1988.

An obituary on Dr Sargant will appear in a future issue of the Bulletin. 